\title{
Effectivity of Expressive Writing Technique to Increase the Emotional Anger Management to 10th Grade Electrical Engineering Student in State Vocational High School 1 Driyorejo, Gresik, East Java
}

\author{
Elisabeth Christiana, Vryscha Novia Ningsih \\ State University of Surabaya, Surabaya, Indonesia \\ e-mail: christiana elisabeth@yahoo.com
}

\begin{abstract}
The purpose of this study is to examine the efectivity of expressive writing techniques with journal therapy to increase the anger management of 10th grade Electrical Engineering Student In State Vocational High School 1 Driyorejo, Gresik, East Java . This type of research is a pre-experiment research with pre-test design posttest one group design. The measuring tool used in this study is a questionnaire of anger management consisting of 41 items. Based on the pre-test results obtained 5 students identified to have a low management of emotional anger score. Data analysis technique used is non parametric statistic by using Wilcoxon Test. Based on calculations that have been done can be known $\mathrm{N}=5$ and $\mathrm{x}=0(\mathrm{z})$, then obtained $\rho=0.042$ with the $\alpha$ of $5 \%$. Based on the calculation, the average pre-test average is 99.4 post-test average 124.4, and the difference between the average pre-test and the post-test average is 25 . Thus Ho is rejected and Ha is accepted. So it can be concluded that expressive writing techniques is efectiv to improve the anger management of 10th grade Electrical Engineering Student In State Vocational High School 1 Driyorejo, Gresik, East Java.
\end{abstract}

Keywords: $\quad$ Expressive Writing Technique, Emotional Anger Management

\section{INTRODUCTION}

The crisis of life of globalization in Indonesia covers various fields, one of them is the field of education. Individu in educational experience facing the various challenges and problems. Individuals are expected to have skills in dealing with various challenges and problems that exist, including in managing their emotions. Managing emotions is an action or an individual's ability to manage emotions and manage the circumstances.

Teenagers have an unstable emotional expression, especially on angry emotions. Teenagers are very sensitive individuals in terms of feelings, easy to get angry. Excessive anger can cause aggression resulting in personal and social life. These problems include hitting friends, cursing, rampaging, fighting, and mass fighting. These kind of actions can make people feel restless.

Based on the results of interviews with school counselors there are problems that occur in State Vocational High School 1 Driyorejo, Gresik, East Java. Starting from fights between friends, fighting to brawl between students that has been happened in State Vocational High School 1 Driyorejo, Gresik, East Java.

From the phenomena above can show that teenagers who get into mass fight and fights itself, are due to not have the management of angry emotions, where they are easily get into emotions that lead to maladaptive actions and also criminal acts according to the realm of law such as fights and brawl.

Teenagers who can manage angry emotions, will be able to survive frustration, can motivate themselves to face the problems, able to control excessive anger, able to set the mood, and empathize and praying. Otherwise, teenagers who are not able to manage angry emotions well, they will be easy to rage, feel insecure, feeling disturbed, feeling hatred, easily get annoy, easily get irritate, feeling impatience, easy to feel frustrate, tense facial expression, loss of self-control while angry. So that students who have low anger management emotion used as research subjects. The selection of research subjects was conducted based on preliminary study 
results conducted through the recommendation from the class teacher and also the school counselor.

So far the solution from the counselor to solve the students' problems are individual counseling services, mediation, and home visit. Schools, including the Principals, Class Teacher, Subject Teachers, and Counselors have also collaborated on dealing with problems around in State Vocational High School 1 Driyorejo, Gresik, East Java. Starting from the holding of home visits if it is necessary, in this case, home visit aimed to ask parents to come to school in the process of solving student problems. Everything done by teachers at State Vocational High School 1 Driyorejo, Gresik, East Java gives little effect to students' problems. Individual counseling, mediation, and home visit services conducted by Counselors are good, but still often encountered by students who have not been able to manage angry emotions. This is indicated by the still tendency of students behave aggressively, because they are still not able to manage angry emotions well so it affects them to achieve progress in life.

In managing angry emotions, there are various activities can be done, including using the technique Expressive Writing by writing down emotional experiences. Writing is one way to pour out feelings and events that have been experienced. The Expressive Writing technique is a form of writing therapy developed by James W. Pennebaker in the late 1980s. The Expressive Writing technique is part of emotion-focused expressive therapy. Where angry emotions are released through writing and can enhance new experiences in individuals. The focus of the research is to know the effectiveness of the expressive writing technique in managing the angry emotions of the students, where there is a process of emotional release when writing, so that the individual is expected to express angry emotions well and not excessively, and behavior change.

Based on the above description, the researchers feel encouraged to make a study on "Efectivity Of Expressive Writing Technique To Increase The Emotional Anger Management To 10th Grade Electrical Engineering Student In State Vocational High School 1 Driyorejo, Gresik, East Java.”

\section{METHODS}

\subsection{Types and Research Design}

Based on the problem formulation and research objectives that hopes to be achieved in this study included in quantitative research. This research uses Pre Experimental Design experiment with research type Pre-test Postest One Group Design. Users of this type are only imposed on one group only without any comparison group.

\subsection{Research subject}

In this research using counseling with expressive writing technique by involving 5 students from $10^{\text {th }}$ grade in Electrical Engineering student State Vocational High School 1 Driyorejo, Gresik, East Java which have low anger management level based on pre-test result.

\subsection{Research Variables and Operational Definition}

In this study there are two variables, namely:

1. Independent Variable

The independent variable in this research is expressive writing technique. The expressive writing technique is an activity of writing the emotional experience felt by the individual without regard to the sentence and diction which is then understood and communicated through interpretation and response.

2. Control Variables

The dependent variable in this study is the management of angry emotions. Anger management of emotions is an individual's ability to recognize, control, and assuage angry emotions, and express anger assertively in order not to cause harmful actions to oneself or others.

\subsection{Data Collecting Instruments}

According to data collection methods used in this study is questionnaire method. In this study, the questionnaire used is a closed questionnaire type and using an alternative answer with a likert scale. The answer of each instrument item using Likert scale has a very positive to very negative level in the form of words as follows: (1) Strongly Agree (2) Agree (3) Less Agree (4) Disagree. 


\subsection{Test Validity and Reliability Instruments}

\section{Validity Test}

Validity is a measure that indicates the level of validity of an instrument. Validity test has been done on students of $10^{\text {th }}$ State Vocational High School 1 Driyorejo, Gresik, East Java as many as 100 students, from $10^{\text {th }}$ grade of Mechanical Engineering 1, Electrical Engineering 1, and Electrical Engineering 2. Research in testing the validity and reliability of the instrument using statistical calculation is using product moment correlation to validity test with SPSS. The result of correlation compared with $r$ table value with significant level $5 \%$. The $\mathrm{r}$ table of $\mathrm{n}=$ 100 is 0.195 Based on the results of validity test of angry management questionnaire from 48 statement items, 41 items of statement declared valid and 7 item statement declared invalid.

2. Reliability Test

Reliability is something quite reliable instrument to be used as a means of data collection because the instrument is good. While to test the reliability of research instruments, researchers use the formula of Alpha Croanbach with SPSS. From the above calculation results, it is known that $r$ arithmetic of 0.806 which then in consultation with $r$ table with a significant level of $5 \%$ is 0.195 (table value of product moment). Then the results obtained rhitung greater than rTable $(0.806>0.195)$ so it can be concluded that the instrument questionnaire pro social behavior in this study stated reliable.

\subsection{Data analysis technique}

The statistical test used to analyze the data is by the Wilcoxon test. Wilcoxon test can be applied if the experimenter wants to get two different conditions: the anger management level before and after being treated through the application of expressive writing techniques. The research hypothesis are:

$\mathrm{H}_{\mathrm{o}}$ : The expressive writing technique is not effectively used to improve the anger management of students' emotions
$\mathrm{H}_{\mathrm{a}}$ : Effective expressive writing techniques are used to improve the anger management of students' emotions

\section{RESULTS AND DISCUSSION}

\subsection{Research result}

\subsubsection{Pre-Test}

Questionnaire pre-test is distributed in $10^{\text {th }}$ Grade of Electrical Engineering, consist of 31 students. The results of pre-test is then categorized into 3 categories namely high, medium and low. Level of anger management category of students are:

A. High category is 132.3 and above

B. Medium category 108,72 to 132,3

C. Low category 108,72 and below

Based on the results of the pre-test questionnaire angry management shown that from 31 students there are 3 students included in the high category, 23 students in the medium category and 5 students in the low category. From the results of the 5 students who fall into the low category serve as the subject of research. Here's a list of students selected as subjects in research:

Table 1. Research Subjetcs

\begin{tabular}{ccccc}
\hline No. & Name & Class & Score & Category \\
1 & AIM & TEI 1 & 99 & Low \\
2 & AA & TEI 1 & 104 & Low \\
3 & CP & TEI 1 & 102 & Low \\
4 & CA & TEI 1 & 97 & Low \\
5 & MRW & TEI 1 & 95 & Low \\
\hline
\end{tabular}

\subsubsection{Treatment Giving}

After doing pre-test, given that 5 students who have low anger management level. Furthermore, students are given treatment in the form of application of expressive writing technique in the groups form. The implementation of expressive writing technique in this research was conducted in six sessions. The details of the treatment of expressive writing techniques are as follows:

\section{a. First Meeting}

Stages: Joining and Rapport Building

Meeting results :

a) The relationship of intimacy between counselor and counselee begins.

b) The counselee is able to understand the management of angry emotions, and the impact if the level of anger management of individual anger is low 
c) The counselee understands the activities to be undertaken during the application of expressive writing techniques

d) The counselee starts writing about the emotional experiences associated with angry emotions.

b. Second meeting

Stages: Developing Self-Awareness

Meeting results :

a) The counselee is interested and open to writing their own emotional experience well

b) Some counselors play an active role in responding to the problems of other counselees.

c) In the reflection process, the counselee already able to realize their inability to manage angry emotions, and it makes them eager to increase their own emotional management.

c. Third Meeting

Stages: Focusing on emotional Processes and

Integration (exploring the worst experience)

Meeting results :

a) The counselee is able to reveal the worst things when they are angry.

b) All counselees begin to appear focused and serious in responding to any problems about excessive anger.

c) Counselors who were previously closed, now they have begin to tell stories and express what they feel well.

d. Fourth Meeting

Stages: Focusing on emotional Processes and

Integration (causes and things that arise angry emotions)

Meeting results :

a) The counselee begins to understand the things that can arise when arising of angry emotions, where they are many that they did not realize before

b) Being aware of the things that can arise when arising of angry emotions, each of the counselee begins to find a solution to overcome it. Not a few of them share solutions because the problems they experience are not much different and interrelated.

e. The Fifth Meeting

Stages: Focusing on emotional Processes and

Integration (writing a letter)

Meeting results : a) The counselee varies in writing letters, some for themselves, while the others for others who have been involved in their emotional experiences.

b) By writing a letter, the counselee feels more relieved and emotionally controlled.

c) The ability of the counselee to control the emotions seems to increase as seen from the opinions they express either directly or through the results of reflection and through written letters, they also give good advice to themselves and others.

\section{f. Sixth Meeting}

Stages: Reflection on self care

Meeting Results: Changes are seen in all counselees, it can be seen from how they faced problems and how he solved problems arising from excessive emotion. In addition, the changes are also felt by the counselee during the intervention session.

\subsubsection{Data of the final measurement result (Post- Test)}

Post test questionnaire is the same as the questionnaire given to the students at the beginning (pre-test). The data obtained from post test results, namely:

Table 2. Hasil Skor Post-Test Angry Emotion Management Questionnaire

\begin{tabular}{cccc}
\hline No. & Subjek & Skor & Kategori \\
1 & AIM & 120 & Intermediate \\
2 & AA & 122 & High \\
3 & CP & 140 & Intermediate \\
4 & CA & 121 & Intermediate \\
5 & MRW & 119 & Intermediate \\
\hline
\end{tabular}

\subsubsection{Analysis of Research Results}

1. Analysis of Pre-Test and Post-Test Results After the pre-test of the class $\mathrm{X}$ students of Electrical Engineering and obtained results, then 5 students who have low anger management level are given treatment by using expressive writing technique in the form of group. Subsequently held post test on the subject of research to determine whether there is an increase in the level of emotional management of angry students after being given treatment. To produce more accurate 
data, the available data were analyzed by using wilcoxon test to know difference of measurement result before and after giving treatment with expressive writing technique in group form to research subject.

Based on the above data, it is known that the sign $(+)$ is 5 and $x$ (number of fewer signs) is 0 . With the terms $\mathrm{N}=5$ and $\mathrm{x}=0(\mathrm{z})$, then $\rho$ (chance value) $=0.042$ Determination $\alpha$ (error rate) of $5 \%$ is 0.05 it can be concluded that $0.042 \leq 0.05$. Based on these results then Ho is rejected and $\mathrm{Ha}$ accepted. After giving expressive writing technique, there is difference of score between pre-test and post-test of anger management level of students. Therefore it was concluded that there was a significant difference in anger management score between before and after expressive writing technique. From the above analysis, it can be said that "expressive writing technique effective to improve the anger management of students' emotion" is acceptable. Thus the treatment with expressive writing technique can effectively improve the anger management $10^{\text {th }}$ Grade students of Electrical Engineering State Vocational High School 1 Driyorejo, Gresik, East Java.

2. Individual Analysis

a. AIM

AIM experienced an increase in anger management score, the pre-test showed 99, while the post-test scored 120. AIM experienced a score increase of 21 points. After being awarded with expressive writing techniques for six AIM meetings showed a better change. During the counseling process AIM is motivated to improve the management of angry emotions and become individuals who are able to manage their angry emotions well. Through writing AIM trying to pour out the angry emotions that had been hold back. During the reflection process, AIM shows a better attitude. AIM is able to learn many things from the process of reflection, where the process of reflection provides many illustrations of how to address the problems it faces when angry emotions emerge. Results after AIM subjects follow treatment with expressive writing techniques shown with good change. Here are the results of the AIM subject graph can be illustrated by the graph below.

b. $A A$

AA subjects experienced an increase in emotional anger management score, the pre-test result showed a value of 104 , while the posttest scored 122. AA experienced a score increase of 18 points. After being given the expressive writing technique for six AA meetings showed a better change. At the beginning of counseling AA showed an indifferent attitude, and often annoyed his other friend. But at the third meeting AA little by little shows the attitude of his attitude, he is more concerned about the problems of his friends and give a response or a good solution. In the next meeting AA increasingly show the change even he always come to the $\mathrm{BK}$ room first than other friends. AA is able to learn many things from the process of reflection, where the process of reflection provides many illustrations of how to address the problems it faces when angry emotions arise. Results after AA subjects follow treatment with expressive writing techniques shown with good change. Here the results of the AA subject graph can be illustrated through the graph below.

c. $C P$

CP subjects experienced an increase in anger management score, the pre-test result was 102, while the post-test scored 140. CP experienced a score increase of 38 points. After being given treatment with expressive writing technique for six times $\mathrm{CP}$ meeting showed a better change. Every CP meeting always looks eager in following counseling that aims to improve the management of angry emotions. CP had difficulty in writing it looks at the results of his writing at the beginning of the meeting but with the guidance and spirit CP became more skilled. Through writing CP trying to pour out the angry emotions that had been hold back. During the reflection process, CP showed a better attitude that can be seen from his attitude in helping provide solutions to his friends who have problems related to angry emotions. CP is able to learn many things from the process of reflection, where the process of reflection provides many illustrations 
of how to address the problems he faces when angry emotions arise. The result after the CP subject followed the treatment with expressive writing technique shown with good change. Here the results of the $\mathrm{CP}$ subject graph can be illustrated by the graph below.

d. $C A$

The CA subjects experienced an increase in anger management score, the pre-test result was 97, while the post-test scored 121. CA experienced a score increase of 24 points. After being presented with expressive writing techniques for six CA meetings showed a better change. During the CA counseling process students are joking. During the reflection process, CA often annoys his friends through his jokes, every time he responds to his friend's problems he is never serious. CA changes begin to appear at the fourth meeting, CA shows its seriousness in the counseling process and shows a better attitude. During the process of reflection, CA can learn a lot, how to change attitudes when angry. The reflection process can provide an idea of how to deal with problems that he and his friend face when angry emotions arise. Results after CA subjects following treatment with expressive writing techniques were shown with good change. The following graph of the CA subject can be illustrated through the graph below.

e. $M R W$

The subject of MRW experienced an increase in anger management score, the pre-test result was 95, while the post-test scored 119. MRW experienced a score increase of 24 points. After being presented with expressive writing techniques during the six MRW meetings showed a better change. During the counseling process MRW is motivated to improve the management of angry emotions and become individuals who are able to manage their angry emotions well. Through writing MRW trying to pour out the angry emotions that had been hold back. During the reflection process, MRW showed a better attitude. MRW is able to learn many things from the process of reflection, where the process of reflection provides many illustrations of how to address the problems it faces when angry emotions emerge. Results after MRW subjects followed the treatment with expressive writing techniques shown with good change. The following results of the MRW subject graph can be illustrated through the graph below.

\subsection{Discussion of Research Results}

The research is a type of pre experimental design by using pre-test and post-test design, is one group of samples given test before and after being given the recognition without any control group as a comparison. In this research using counseling with expressive writing technique by involving students from class $10^{\text {th }}$ majoring in Electrical Engineering State Vocational High School 1 Driyorejo, Gresik, East Java which has low level of anger management.

From the predetermined class, the pretest is done to find out the initial score in the anger management questionnaire before being given the treatment of expressive writing technique. Based on the results of a questionnaire of anger management that has been done as a pre-test, five students have low anger management level, 23 students have moderate anger management level, and three students with high anger management level. To help improve the management of angry emotions then given treatment with expressive writing techniques.

The results of the analysis conducted during the treatment process found the problems of students who are often encountered, among others, when angry things are done to damage the goods around, make fun of people who have made him angry, and fight with friends who make offense, such as ridiculed, slandered, Beaten. From the problem then given the treatment of expressive writing technique. According Peannebaker \& Chung (2007), expressive writing benefits is a therapy that is able to develop an understanding in the face of problems and reactions to the problem. The expressive writing technique is aimed at students who have low anger management emotion and are expected to improve their anger management better through writing. Counseling is given during six meetings to help students improve the management of their angry emotions. Expressive writing techniques are given to 
students who have low levels of emotional anger management.

In the process of applying the expressive writing technique goes well, but there are still some obstacles in the implementation. Because previously BK teachers have never conducted group counseling services but do classical classroom counseling, individual counseling, and home visits. So at the beginning of the implementation of the students are still a lot of questions and do not know how the implementation of group counseling. Another obstacle is creating students 'willingness to write students' emotional experiences into a journal. For them writing is boring, so patience and counselor's patience is required in guiding them into exploring their emotional experiences and pouring them into writing. Then the students are given back the same angry management questionnaire (post-test) with a questionnaire before the treatment. After obtaining the results of research in the form of quantitative data, then the data is analyzed using non parametric statistics with wilcoxon test.

Based on the results of the wilcoxon test analysis it is known that the sign (+) is 5 as $x$ (number of fewer signs) is 0 . With the terms $\mathrm{N}=5$ and $\mathrm{x}=0(\mathrm{z})$, then $\rho$ (possibly the price below Ho ) $=0.042$ If in the determination $\alpha$ (error rate) of $5 \%$ is 0.05 then it can be concluded that 0.042 $<0.05$. Based on these results then $\mathrm{Ho}$ is rejected and $\mathrm{Ha}$ accepted. After giving expressive writing technique, there is difference of score between pre-test and post-test of anger management level of students. Therefore it is concluded that there is a significant difference in the anger management score of emotion between before and after giving expressive writing technique. From the above analysis, it can be said that the hypothesis proposed in this study, namely "Effective expressive writing techniques used to improve the management of angry emotions of students" is acceptable. Thus the treatment with expressive writing techniques can improve the anger management angry students of class $10^{\text {th }}$ Electrical Engineering State Vocational High School 1 Driyorejo, Gresik, East Java.

\section{CONCLUSIONS AND SUGGESTION}

\subsection{Conclusion}

This research was conducted to test the utilization of expressive writting technique to help improve anger management of students' emotion. This research was conducted at State Vocational High School 1 Driyorejo, Gresik, East Java in class $10^{\text {th }}$ of electro technique with low level of anger management emotion. Based on the pre-test results obtained 5 students selected as research subjects. 5 students as subjects of this study were given treatment sebayak 6 times, in the process of giving treatment of research subjects were asked to write emotional experience related to angry emotions'.

The results of the research show that "expressive writing technique can improve anger management of 5 students of class $10^{\text {th }}$ of electrical engineering". This conclusion is based on the results of the sign test that is known $\mathrm{N}=5$ and $\mathrm{x}=0(\mathrm{z})$, then obtained $\rho$ (possibly price below Ho) $=$ 0.042 . If the $\alpha$ (error rate) of $5 \%$ is 0.05 then it can be concluded that the price is $0.042<0.05$. Based on this result then Ho is rejected and $\mathrm{Ha}$ accepted. Furthermore, from the calculation, the average pre-test is 99.4 and the average post-test is 124.4 , so it can be said that expressive writing technique can improve anger management of class $10^{\text {th }}$ students of electrical engineering in State Vocational High School 1 Driyorejo, Gresik, East Java.

\subsection{Suggestion}

From research that has been done researcher can give suggestion as follows:

1. For school counselors

Counselors are expected to apply counseling with expressive writing techniques in providing guidance and counseling services especially in helping to improve the anger management of students' emotions.

2. For the school

The results of this study are expected to be an input for schools in the implementation of counseling guidance in schools.

3. For other researchers

This research can be used as a reference and can be developed in doing further research related to expressive writing techniques. 


\section{REFERENCES}

[1] Adams, Kathleen. 1999. Writing as therapy: Counseling and Human Development. ProQuest Education Journals. pg. 1

[2] Arifin, Sandi (2015). “Masalah Kenakalan Remaja." (Online),(http://anneahira. com .masalah-kenakalan-remaja. Accessed on May 14, 2016 at 11 am

[3] Arikunto Suharsimi. 2010. Manajemen Penelitian. Jakarta: Rineka Cipta.

[4] Baikie dan Wilhelm, K. 2005. Emotional and Physical Health Benefits Expressing Writing. Advances in Psychiatric Treatment. No.11. Hal. 338-346

[5] Chaplin, J.P. 2012. Kamus Lengkap Psikologi. Jakarta : Rajawali Press.

[6] Goleman, Daniel. 2015. Emotional Intellegence. Jakarta: Gramedia Pustaka. Greenberg, L.S \& Watson, J.C. 2006. EmotionFocuced Therapy for Depression. Washington DC: American Psychologikal Association.

[7] Groves, Judi \& Huber, Tonya. Art and anger management. The Clearing House Vol. 4, No. 76 (hal. 186-192).

[8] Metro News. 2015. Angka Kenakalan Remaja. Metro.com, (Online), (http://metro.news.viva. co.id. Accessed on August 19, 2016 at 8 pm

[9] Natawidjaya, Rochman. (2009). Konseling Kelompok Konsep Dasar \& Pendekatan. Bandung: Rizqi Press.

[10] Niederhoffer, K. G., \& Pennebaker, J. W. 2009. Sharing one's story: On the benefits of writing or talking about emotional experience. In S. J. Lopez \& C. R. Snyder (Eds.), Oxford Handbook of Positive Psychology (pp. 621-632). New York: Oxford University Press.

[11] Noor, Juliyansyah. 2011. Metodologi Penelitian. Jakarta. Kencana Prenada Media group.

[12] Pennebaker, J.W. 1997. Opening up: The healing power of expressing emotion. New York: Guilford Press.
[13] Reksoatmodjo, T. N. 2007. Statistika untuk Psikologi dan Pendidikan. Bandung: PT. Refika Aditama.

[14] Riska, Agustinawati. 2012. Pengaruh minat belajar, ekonomi keluarga, dan fasilitas belajar sekolah terhadap prestasi belajar siswa pada mata pelajaran akutansi (Survei pada sisa kelas XII IPS SMA Negeri 12 Bandung). UPI Essay. Unpublished

[15] Rita susanti, Desma Husni, Eka Fitriyani. 2014. Perasaan Terluka Membuat Marah. Journal of Psychology, Vol. 10, No. 2.

[16] Santrock, J. W. 2007. Adolescence (Perkembangan Remaja). Terjemahan. Jakarta: Penerbit Erlangga.

[17] Sugiyono. 2015. Metode Penelitian Kuantitaif Kualitatif dan $R \& D$. Bandung: Alfabeta.

[18] Tim. 1990. Kamus Besar Bahasa Indonesia. Jakarta: Balai Pustaka.

[19] Pennebaker, J. W., \& Chung, C. K. 2007. Expressive writing and its links to mental and physical health. In H. S. Friedman (Ed.), Oxford handbook of health psychology. New York, NY: Oxford University Press.

[20] Hershorn, Michael. 2002. 60 second Anger Management. Jakarta: PT: Bhuana Ilmu Populer.

[21] Mulyadi, Seto. 2004. Membantu Anak Balita Mengelola Amarahnya. Jakarta: Erlangga.

[22] Albin, Rochelle Semmel. 1999. Emosi. Yogyakarta: Kamsius.

[23] Safaria \& Saputra. 2012. Manajemen Emosi. Jakarta: Bumi Aksara.

[24] Qonitatin, Novi dkk. 2011. "Pengaruh Katarsis dalam Menulis Ekspresif sebagai Intervensi Depresi Ringan Pada Mahasiswa". Journal of Psychology UNDIP. Vol. 9, No. 1.

[25] Purwanto, Yadi dan Mulyono, Rachmat. 2006. Psikologi Marah. Bandung: Refika Aditama. 